\title{
Candidal Retinitis
}

Carl D. Mele

Thomas Jefferson University

Follow this and additional works at: https://jdc.jefferson.edu/tmf

Part of the Ophthalmology Commons

Let us know how access to this document benefits you

\section{Recommended Citation}

Mele, Carl D. (2003) "Candidal Retinitis," The Medicine Forum: Vol. 4 , Article 12.

DOI: https://doi.org/10.29046/TMF.004.1.012

Available at: https://jdc.jefferson.edu/tmf/vol4/iss1/12

This Article is brought to you for free and open access by the Jefferson Digital Commons. The Jefferson Digital Commons is a service of Thomas Jefferson University's Center for Teaching and Learning (CTL). The Commons is a showcase for Jefferson books and journals, peer-reviewed scholarly publications, unique historical collections from the University archives, and teaching tools. The Jefferson Digital Commons allows researchers and interested readers anywhere in the world to learn about and keep up to date with Jefferson scholarship. This article has been accepted for inclusion in The Medicine Forum by an authorized administrator of the Jefferson Digital Commons. For more information, please contact: JeffersonDigitalCommons@jefferson.edu. 


\section{Candidal Retinitis}

Submitted by Carl D. Mele, MD
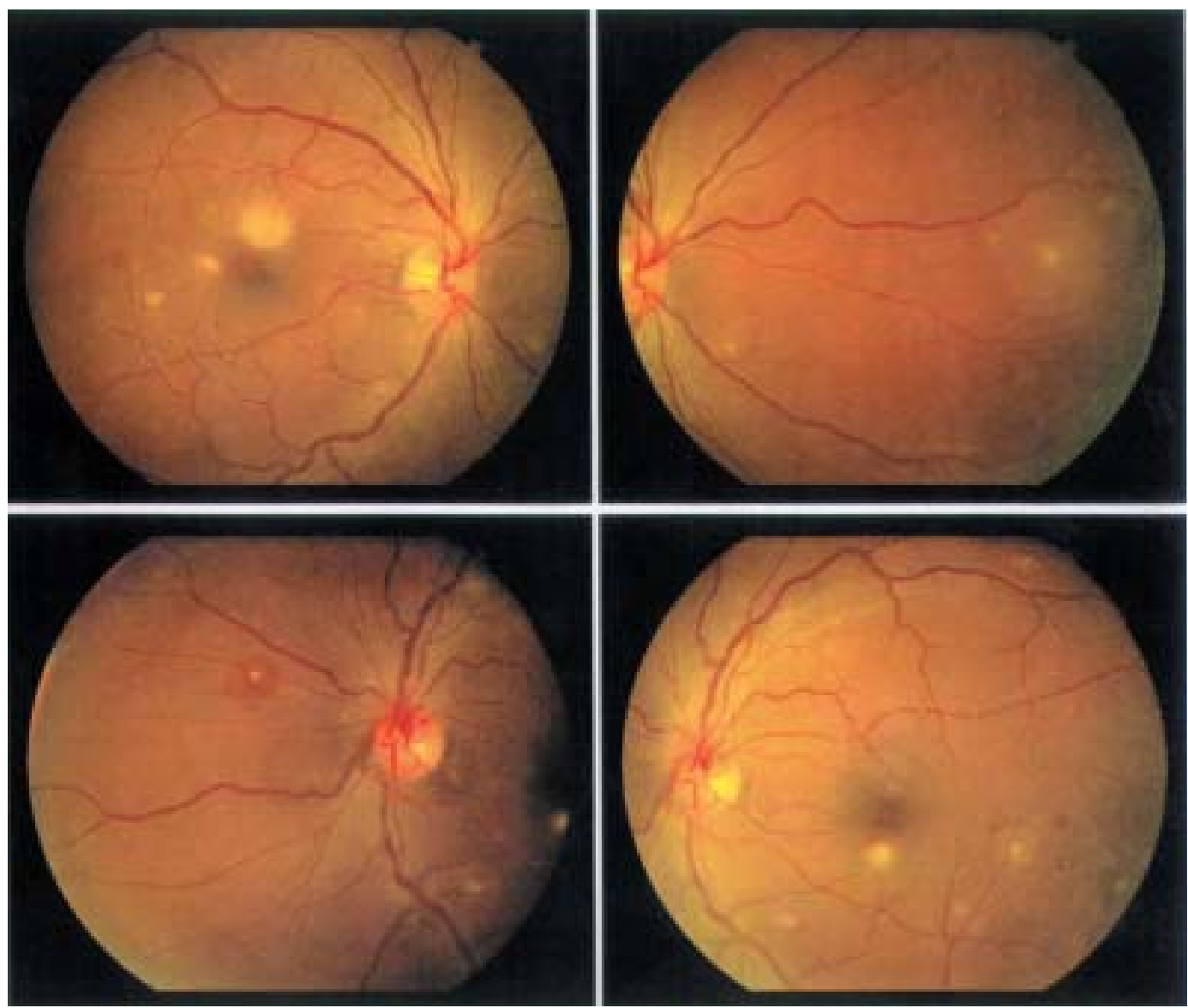

Mr. R.T. was a 49 year old male with recurrent Hepatitis $\mathrm{C}$ infection after orthotopic liver transplant, who presented with complications related to hemorrhagic pancreatitis. While on long term total parenteral nutrition, he developed blurry vision and Candida albicans fungemia. A fundus photograph revealed fungal endopthalmitis with focal areas of chorioretinitis. His vision improved significantly with serial intravitreal antifungal injections.

\section{Histology Slide}

\section{Submitted by John Farber, MD, Department of Pathology}

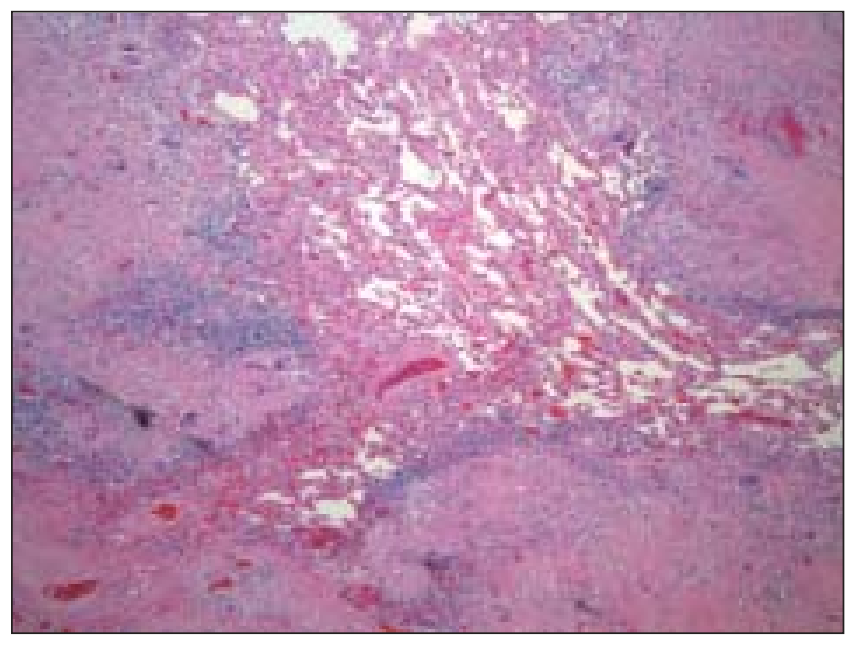

A 45 year old Black female without significant past medical history was admitted with insidious cough, dyspnea, nausea, vomiting, and progressive weight loss. She suddenly went into respiratory distress and succumbed to death. Autopsy subsequently showed widespread granulomatous disease. This slide of one of the lung lesions shows a noncaseating granulocyte with a fibrotic center surrounded by palisading histiocytes, consistent with a diagnosis of nodular sarcoma. 